\title{
Congenital retinoblastoma - Report of a case
}

\author{
Retinoblastoma congênito - relatodecaso
}

\author{
Ana Beatriz Sacchetto Ungaro ${ }^{1}$ \\ Sergio Lustrosa da Cunha ${ }^{2}$ \\ Ruth Miyuki Santo ${ }^{3}$
}

${ }^{1}$ Residente do $3^{\circ}$ ano do Departamento de Oftalmologia da Faculdade de Medicina da Universidade de São Paulo - USP.

${ }^{2}$ Professor Associado do Departamento de Oftalmologia da Faculdade de Medicina da Universidade de São Paulo - USP.

${ }^{3}$ Doutora Assistente do Departamento de Patologia da Faculdade de Medicina da Universidade de São Paulo - USP.

Endereço para correspondência: Av. Angélica, 1757 - $5^{\circ}$ andar - São Paulo (SP) CEP 01220-200.

Recebido para publicação em 06.07.2001 Aceito para publicação em 15.05.2002

Nota Editorial: Pela análise deste artigo e por sua anuência sobre a divulgação desta nota, agradecemos à Dra. Clélia Maria Erwenne.

\begin{tabular}{|c|}
\hline ABSTRACT \\
\hline The authors present an unusual case of bilateral retinoblastoma, showing \\
early appearance (bilateral leukocoria at 1 month of age), "phthysis bulbi" \\
in OD and massive calcification of the vitreous cavity.
\end{tabular}

Keywords: Eye neoplasms; Retinal neoplasms/genetics; Retinoblastoma/congenital; Case report

\section{INTRODUCTION}

Retinoblastoma is the most common intraocular tumour in childhood; characteristically aggressive, it initially involves the globe, with posterior extension to the cranium and central nervous system via optic nerve, orbit and metastatic spreading to the whole body excluding the lungs.

The average age for diagnosis varies from 12 months in bilateral cases to 23 months in unilateral tumours ${ }^{(1)}$.

This report refers to a case of retinoblastoma with an unusual course, early appearance in both eyes, rapid growth with extensive necrosis and a right phthysical eye (Figure 1).

\section{REPORT OF A CASE}

C.A.S., a three-month-old female with one-month history of ocular inflammation and leukocoria in both eyes. The parents report that she had normal eyes at birth. No similar cases were known in the family.

External ocular examination revealed: lid inflammation with corneal edema, anterior chamber with flare and cells and leukocoria in both eyes. OD was reduced in size with no pupillary reaction. OS had normal size, with ocular hypertension and "glaukomflecken"; pupillary reaction was normal to light.

CT and ultrasonography showed similar features: plaques of calcification filling most of the vitreous chamber in both eyes (Figure 2).

All extraocular structures had been considered normal.

After a long interview with the parents and due to the advanced stage of the tumor, enucleation was advised and done in both eyes.

\section{Pathology}

OD Macroscopy - globe measuring $14 \times 14 \mathrm{~mm}$ (horiz. $\mathrm{x}$ vertical) and $15 \mathrm{~mm}$ (axial); cornea with 9x7 mm, a small segment of the optic nerve was left on the piece. Massive calcified substance filling the vitreous cavity (Figure 3 ).

OD Microscopy - a few small areas of viable tumor cells, some forming Flexner-Wintersteiner and Homer-Wright rosettes. The retinal pigment epithelium was disorganized but there was no sign of choroidal invasion. The remaining optic nerve was free of neoplasia (Figure 4).

OS Macroscopy - globe measuring 18x18 mm (horiz. x vertical) and $20 \mathrm{~mm}$ 


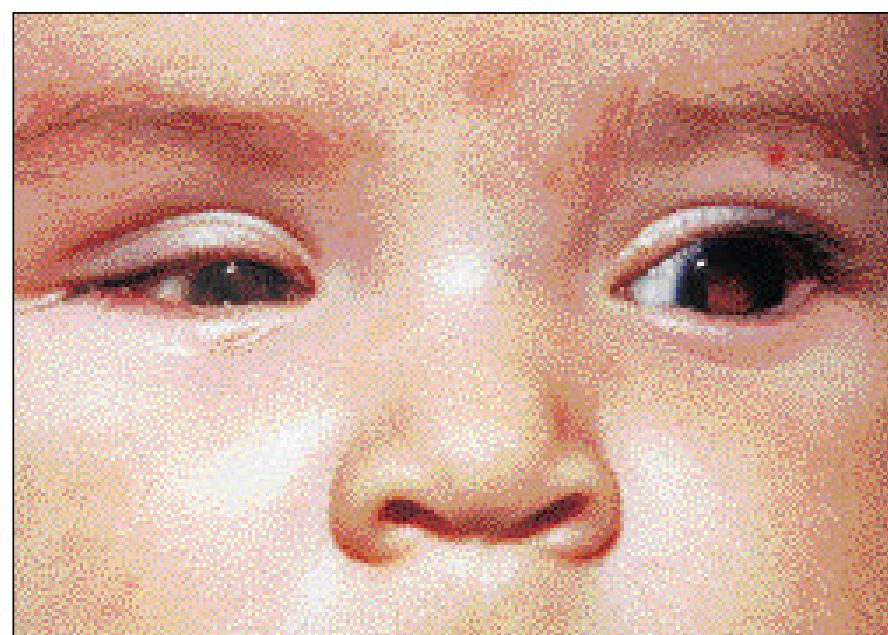

Figura 1 - Patient's aspect on the day of presentation (2 months and 26 days old): Bilateral leukocoria and phthysical aspect of the right eye

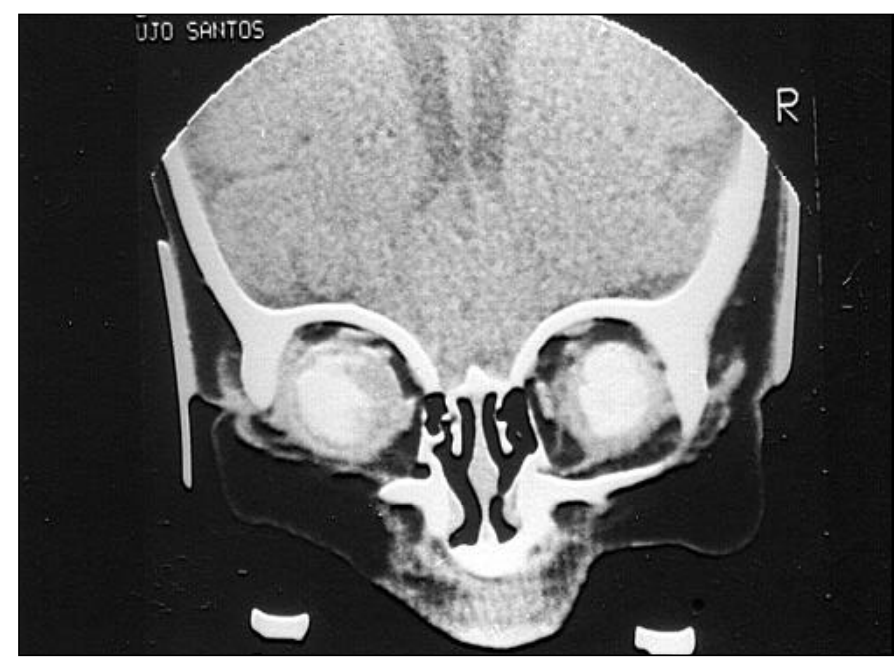

Figura 2 - Massive calcification of vitreous cavity in both eyes - CT

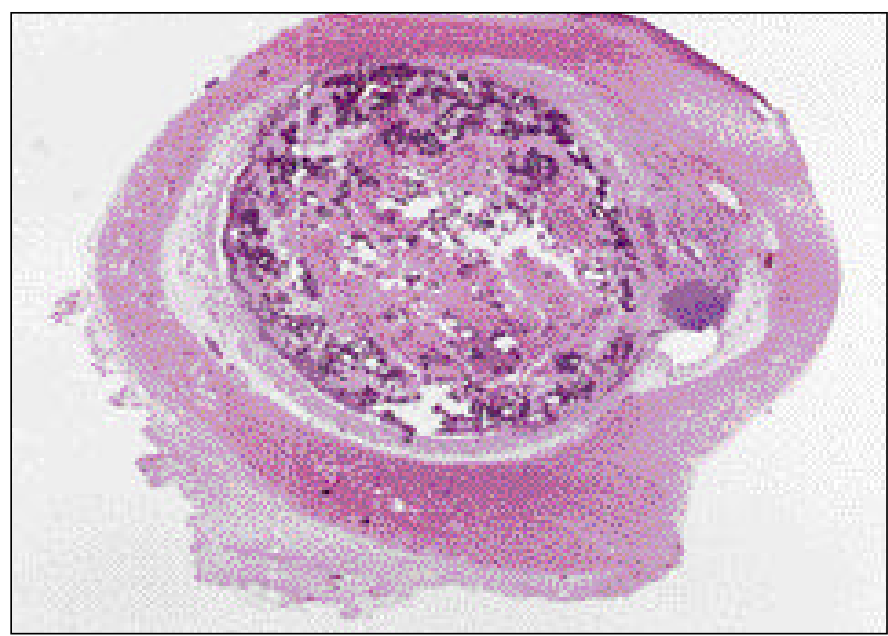

Figura 3 - OD: Macroscopy. Globe measuring 15x15 mm, cornea with $9 \times 7 \mathrm{~mm}$. A small segment of the optic nerve and massive calcification in the vitreous cavity

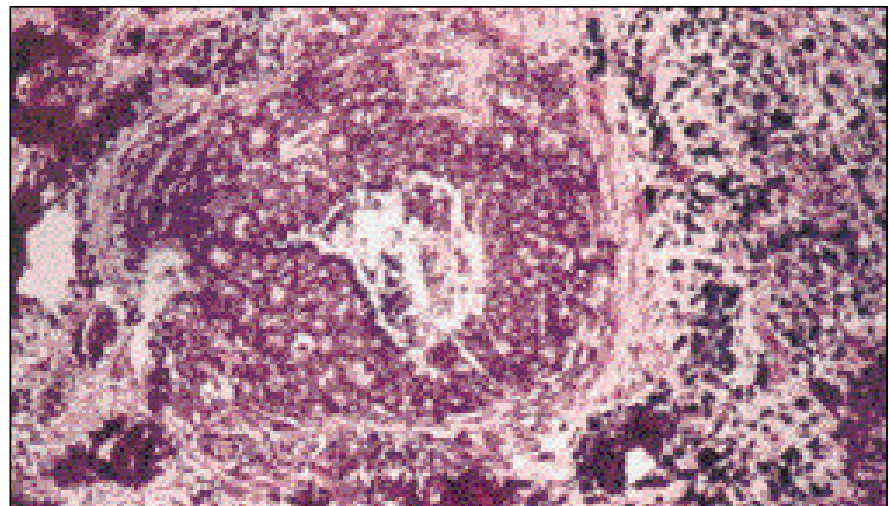

Figura 4 - OD: Microscopy. Few areas of visible tumor cells. Rosettes of Flexner-Wintersteiner and Homer-Wright. No sign of choroidal or optic nerve invasion. (H.E. x 200)

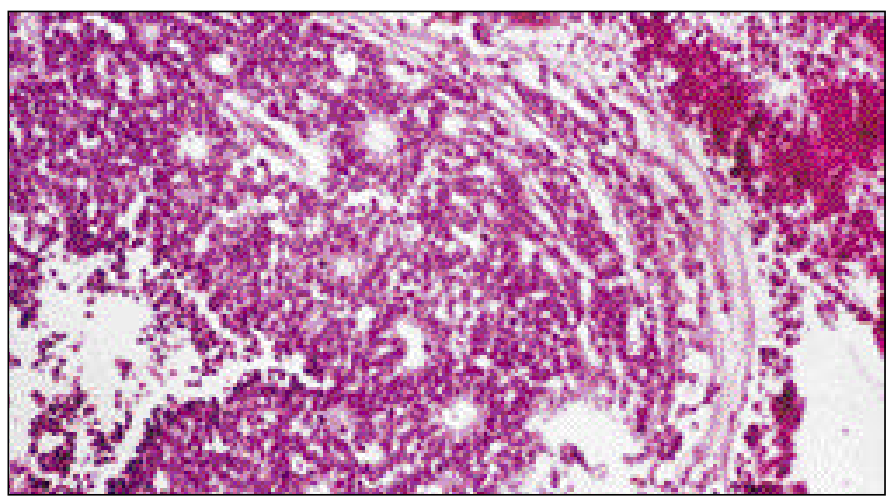

Figura 5 - OE: Areas of viable tumor cells showing the same Rosettes configuration

(axial); cornea with $11 \mathrm{~mm}$, anterior chamber with a level of pseudohypopyon; the same calcified white substance fills the inferior vitreous cavity surrounded by hemorrhage.

OS Microscopy - more than $80 \%$ of the area is formed of necrotic tumor tissue.

Some small areas of viable retinoblastoma cells forming the same rosette configuration. Tumor cells were found in the ciliary body, iris surface and posterior cornea. There was no sign of choroidal invasion and the optic nerve was free of neoplasia (Figure 5).

\section{Comment}

Retinoblastoma as a highly malignant intraocular tumor requiring an early diagnosis and immediate treatment.

The purpose of this presentation is to highlight several uncommon manifestations of retinoblastoma, such as:

1 - Bilateral leukocoria at two months of age.

2 - Phthysical right eye at first examination.

"Retinoblastoma never occurs in a microphthalmic eye"* (Verhoeff)

There are currently only five reports of retinoblastoma occurring in a microphthalmic eye $\mathrm{e}^{(2-6)}$.

* Personal communication by Sergio L. Cunha M.D 
3 - The presence of calcium is diagnostic of retinoblastoma in infants less than 2 years old.

The amount of calcium in our case, plaques filling almost the whole vitreous cavity of both eyes (ultrasound and CT scan) is a very rare finding in retinoblastoma.

The so called "spontaneous regression" of the retinoblastoma occurs when severe inflammation and massive necrosis develop, leading to a phthysical eye, as in our case.

\section{RESUMO}

Os autores apresentam um caso raro de retinoblastoma bilateral caracterizado por aparecimento precoce (leucocoria bilateral com um mês de idade), grande redução do volume em OD por "phthysis bulbi” e calcificação maciça da cavidade vítrea.
Descritores: Neoplasias oculares; Neoplasias da retina/genética; Retinoblastoma/congênito; Relato de caso

\section{REFERENCES}

1. Shields JA, Shields CL. Intraocular tumors: a text and atlas. Philadelphia: W.B. Saunders; 1992 .

2. Levine AR, Albert DM, Sang DN. Retinoblastoma with persistent hyperplastic vitreous. Invest Visual Sci 1997;16:403-7.

3. Axelsen I. Retinoblastoma in a microphthalmic eye. Ophthalmologica 1978; 176:27-33.

4. Morgan KS, McLean IW. Retinoblastoma and persistent hyperplastic vitreous occurring in the same patient. Ophthalmology 1981;88:1087-90.

5. Liang JC, Augsburger JJ, Shields JA. Diffuse infiltrating retinoblastoma associated with persistent primary vitreous. J Pediatr Ophthalmol Strabismus 1985;22:31-3

6. Jong SL, Young KS, Jung G. Retinoblastoma which developed in microphthalmia. Acta Ophthal 1997;75:730-1.

\title{
Curso de Urgências em Offalmologia
}

\author{
13 e 14 de Dezembro de 2002
}

\section{Promoção:}

\section{Centro de Estudos do Instituto CEMA}

\section{INFORMAÇÕES: Fone: (11) 6604-8662}

E-mail: centrodeestudos@cemahospital.com.br 